\title{
Što bi Isus učinio u modelu poučavanja na daljinu?
}

\author{
Maja Seguin \\ Visoko evanđeosko teološko učilište u Osijeku - visoka škola \\ maja.seguin@evtos.hr
}

UDK: 2-75:27-246:37.091.3

Stručni rad

https://doi.org/10.32862/k1.15.1.3

\section{Sažetak}

Uslijed prelaska s tradicionalnog na virtualno poučavanje, nastaju razna pedagoška preispitivanja te je nužno omogućiti učiteljima primjer pristupa poučavanju i učenju. Ovaj članak daje pregled modela poučavanja koji je Isus koristio, posebice prispodobe ili parabole, ističe model suvremenoga konstruktivističkog poučavanja te izdvaja karakteristike konstruktivizma u Isusovu modelu. Sve to predstavlja osnovu za praktične savjete u današnjem kontekstu poučavanja na daljinu, odnosno u virtualnom kontekstu. Članak izdvaja karakteristike Isusa kao učitelja koje suvremeni učitelji mogu preslikati u svom kontekstu te završava smjernicama za daljnja moguća područja istraživanja.

Ključne riječi: prispodobe, parabole, konstruktivistički pristup procesu učenja, učenje na daljinu, online učenje

\section{Uvod}

U posljednjih godinu dana, više nego ikad, poučavalo se na daljinu, koristeći internet, razne aplikacije pa je potreba za nužnim, brzim savladavanjem tehnoloških vještina i prilagođavanjem na virtualne učionice i zadatke postala vrlo očita i stvarna. Teološke ustanove, uključujući biblijske škole, stavljene su pred još veći izazov jer dio njihova nastavnog programa uključuje aspekt zajedništva koji se ostvaruje u neposrednom kontaktu s drugima. Učionice, zajednički prostori, zamijenjeni su onim virtualnim, a učitelji su stavljeni pred izazov u kojem nastoje prenositi znanja, umijeća, vještine i vrijednosti koja se mogu povezati s učeniko- 
vim svakodnevnim iskustvima. Sve to zahtijeva i određene učiteljeve kompetencije u pristupu poučavanja.

Ovaj članak ima za cilj izložiti glavni model poučavanja (Hultgren 2000, 1) koji je Isus koristio - prispodobe, objasniti konstruktivistički pristup procesu učenja, navesti karakteristike konstruktivističkog pristupa procesu učenja u modelu Isusova poučavanja i dati praktične savjete za poučavanje u današnjim okolnostima kada su učitelji primorani poučavati na daljinu. Sve to može nam pomoći uvidjeti na koji način suvremeni učitelji mogu slijediti Isusov primjer u svojim učiteljskim nastojanjima na daljinu.

Rad se neće baviti preciznim definiranjem modela Isusova poučavanja, konkretnim brojem uporabe metode, jezičnim specifičnostima niti teološkim interpretacijama, već će nastojati odgovoriti na pitanja postoji li nešto iz Isusova poučavanja što bismo mogli primijeniti u suvremenim učionicama, posebice $u$ nastavi na daljinu, te koje su to karakteristike koje bi se mogle preslikati u današnji kontekst. Cilj rada nije doprinijeti tumačenju prispodoba, već izvući nekoliko ključnih karakteristika o načinu na koji je Isus poučavao, o karakteru koji je preslikavao svojim učenicima te što bismo mogli, kao učitelji u suvremenom i digitalnom kontekstu preslikati svojim učenicima. Također, cilj ovog rada nije tvrditi da je Isus poučavao na daljinu, niti radom ukazati na superiornost virtualnog ili inferiornost tradicionalnog pristupa učenju, ili obratno.

\section{Isusov model poučavanja}

\subsection{Isus - učitelj}

Od četrdeset naziva, koji opisuju Isusa, u evanđeljima se posebno ističe onaj koji ga opisuje kao „učitelja“ (Stein 1978, 1). Razlikovao se u mnogočemu od rabina svog vremena, od načina na koji je poučavao, sadržaja svoje pouke, mjestima izlaganja do povezanosti sa svojim učenicima, uključujući odnos prema marginaliziranima (Stein 1978, 2). Iako nije koristio suvremena pomagala dostupna današnjim učiteljima, uspio je zadobiti pažnju svojih slušatelja. Ponekad je bio i previše popularan i njegova su predavanja privlačila mnoštva te je kao učitelj morao poučavati s lađice $(\mathrm{Mk} \mathrm{4,1)}$. Mnoštva su bila privučena ne samo onime što ih je Isus učio već i onime kakav je bio.

Stein $(1978,8)$ navodi da je Isus imao autoritet, davao je poruku popraćenu čudima i znamenjima te je imao svojevrsne stilske metode iako te metode i načini na koje je poučavao nisu predstavljali znanstveni pristup koji danas zahtijevamo i očekujemo od svojih učenika i studenata. U svom poučavanju je od stilskih metoda koristio pretjerivanje, preuveličavanje, dosjetke, poredbe i prispodobe, metafore, izreke, zagonetke, paradoks, retoričke argumente, ironiju, pitanja te poetski 
paralelizam, a neke od tih se u sinoptičkim evanđeljima koriste za prepoznavanje prispodobe ili parabole (Hultgren 2000, 2) koja se tiče ovoga rada. Isus je, u svom vremenu i kontekstu, inovativni predavač kada koristi prispodobe ili parabole. $\mathrm{U}$ rabinskoj literaturi prije Isusova vremena ne nalazi se ni jedna prispodoba (Jeremias 1972, 12; Porton 2006, 207), a ni u bliskoistočnoj i grčko-rimskoj literaturi (Schottroff 2006, 105) koje po sadržaju i funkciji podsjećaju na Isusove. Njegova pouka, njegove prispodobe, razlikuju se od druge pouke njegovih preteča, suvremenika i nasljednika (Breech 1989, 24).

Odlomak koji slijedi tiče se jedne stilske metode koju je Isus koristio u svom poučavanju, a to je prispodoba ili parabola. Parabola, kao literarna figura, u radu se neće posebice razlikovati od drugih figura koje bi se također mogle protumačiti istim pojmom. Dakle, u ovom radu se o paraboli piše u vrlo širokom smislu.

\subsection{Isusovo korištenje prispodoba ili parabola}

Najupečatljivije, najutjecajnije i rasprostranjene kao izrazi su prispodobe ili ilustrativne priče, koje je Isus koristio (Snodgrass 2008, 1). Narativa prispodobe je slikovita te fiktivna priča s primjenom (Schottroff 2006, 103). Isus je bio savršeni stvaratelj priča, koji je njima zadržavao pažnju, poticao, upućivao, zaokupirao. Priče potiču na razmišljanje i procjenjivanje, ali su i najbrži alat u učenju (Snodgrass 2008,1$)$. One su pune ilustrativnih figura i ostavljaju dublji utisak na um od apstrakcija (Jeremias 1972, 11) jer se slušatelj može pronaći u sebi poznatim i razumljivim okolnostima. No Isusove parabole daju proširenu analogiju s usporedbama i uspostavljaju retoričku poantu (Snodgrass 2008, 2). Može ih se doživjeti kao živopisne moralne pouke primjerene i za mlađe uzraste, ali i poput oružanoga govora nekog političara u žestokoj kampanji (Hunter 1979, 9).

Riječ parabola posuđenica je iz grčkog jezika čije se značenje odnosi na „usporedbu“ kojom je Isus u svom poučavanju uspoređivao vječne realnosti s onim uobičajenim i svakodnevnim tog vremena (Hultgren 2000, 2). Snodgrass (2008, 7) upozorava da su prispodobe više od priča te, iako sadrže elemente eshatologije, usmjerene su na život na zemlji. Kroz prispodobe, Isus je poučavao iz životnih primjera u okruženju u kojem se nalazio, improviziranim, a ne elaboriranim, u živom susretu s ljudima (Hunter 1979, 12), a poučavao je o dolasku kraljevstva Božjeg (Mk 1,14-15; Mt 4,23; Lk 4,42-43), o svom Ocu Bogu te o važnim etičkim načelima po kojima trebamo biti poput Boga (Snodgrass 2008, 2). Isusove parabole radikalno poučavaju o kraljevstvu, političkim i socio-političkim temama te tako predstavljaju i umjetničko i oružano djelo, koje donosi jednima pouku, a drugima uvredu (Snodgrass 2008, 2), štoviše, jer se uglavnom tiču nečega nastalog iz sukoba, od opravdanja do napada (Jeremias 1972, 21). Schottroff (2006, 103 ) ističe da narativa prispodobe ne opisuje neki povijesni događaj, već izlaže o svojevrsnoj strukturi i međusobnim društvenim odnosima, primjerice, obojenim 
krajnostima nepravednosti bogatih i patnji siromašnih. Isus je pričao fikciju koja se shvaćala istinitom jer su je slušatelji mogli predočiti u svom kontekstu (Breech 1989, 60).

Na pitanje zašto Isus koristi prispodobe, moguće je dati različite odgovore: a) kako bi slikovito prikazao svoje učenje i tako izazvao intelektualno shvaćanje i razumijevanje koje dolazi od slušanja glasa Božjeg (Schottroff 2006, 105); b) kako bi prikrio potpuno značenje svoje poruke od onih koji bi mogli pogrešno i iz političkih razloga krivo protumačiti pouku; c) kako bi svoje slušatelje mogao argumentirano „razoružati“ (Stein 1978, 42). No Isus svoje parabole ne koristi u smislu filozofskog argumentiranja i retoričke nadogradnje principa jer u svom poučavanju ne zahtijeva od svojih učenika prethodno znanje, osim onoga što su već iskusili u životu (Hultgren 2000, 9). Prispodobe su model polemičkog poučavanja, u kojima Isus uspoređuje nepoznato s poznatim te strano s bliskim (Hunter 1979, 10).

Iako Isusovi prvotni slušatelji nisu bili kršćani te je njegova pouka bila naročito vrijedna kao alat poučavanja sekularne publike (Jones 1999, 6), Isus je poučavao u prispodobama, koje su bile uključujuće, proaktivne, pozivale na zauzimanje stava svezi toga tko je Isus i što je njegovo poslanje (Jeremias 1972, 30). Prispodobe zahtijevaju aktivno sudjelovanje slušatelja, ali i odgovor u obliku stava ili popratnog djelovanja, koji treba odraziti ispravno razumijevanje izrečene pouke (Schottroff $2006,104)$. Na taj način izazivaju presudu ili pozivaju na davanje odgovora, i to često kroz njegova pitanja poput „Što mislite...?“ (Hunter 1979, 12). Hultgren $(2000,8)$ primjećuje da se Isus u svojim parabolama izravno obraća svojim slušateljima prodornim pitanjima („Tko to od vas ... ?" , „Koja to žena ... ?“, „Tko među vama ... ?") jer takvi uvodi odmah zaintrigiraju slušatelje, učine ih dijelom pouke i zahtijevaju odgovor. Odgovor predstavlja taj obavezni dio pouke, a traži se kroz mnoga retorička pitanja ili otvoreni zaključak u Isusovim prispodobama. Hunter shvaća svrhu prispodobe u "gledanju, prosuđivanju, djelovanju“ (Hunter $1979,13)$, a Bailey $(1983,40)$ je u svakoj prispodobi pronalazi tri djela - narativni, odgovor u smislu djelovanja ili prihvaćanja novog razumijevanja Božjeg ophođenja te promišljanje o teološkim porukama koje podcrtavaju učenikov odgovor.

No Isusov model poučavanja otkriva nam model i karakter učitelja. U sljedećem odlomku ističu se neke karakterne crte učitelja, koje nam također mogu poslužiti $\mathrm{u}$ vlastitim nastojanjima preslikavanja uzora u nastavničkom pristupu.

\subsection{Isusov model poučavanja otkriva karakter učitelja}

Isus kroz svoje prispodobe pokazuje da dobro poznaje svoje učenike - zna njihov kontekst i običaje (Schottroff 2006, 118). Isusa ne zanima klasna podjela, već pokazuje osobni interes za pojedinca te u svojim postupcima ne daje mjesta ponosu i samodopadnosti. U svom poučavanju i postupcima vrlo je odnosan i traži da se 
naučeno primjenjuje u odnosima i odražava u načinu na koji gledamo i postupamo prema drugima. Zato dopušta grešnici da mu ljubi te pere suzama i kosom noge i uči Šimuna da mijenja svoje stavove. Isus posebnu pažnju daje „problematičnima“, onima koji nemaju prepoznat uspjeh i koji nisu prihvaćeni u svojoj okolini, onima najmanjima, izgubljenima i zadnjima - izgubljenom novčiću i izgubljenoj ovčici (Hunter 1979, 56).

Nadalje, poznaje retoričke principe efektivnog izlaganja i pritom koristi anegdotska pravila - pravilo kontrasta, pravilo priče s tri lika (tri prolaznika u priči o dobrom Samarijancu, tri izgovarača iz priče o velikoj večeri, tri sluge iz priče o talentima) te pravilo naglašavanja krajnjeg lika ili djela u priči (Hunter 1979, 12). Isus u svome narativnom diskursu ne upotrebljava neupravni govor i tako čini da su likovi o kojima govori prisutni (Breech 1989, 68). O onome što poučava, Isus govori sa znanjem i pouzdanjem (Hunter 1979, 57) te autoritetom. Breech $(1989,67)$ nije zapazio ni jednog drugog naratora u zapadnoj antici koji s takvim autoritetom govori isključivo prema svojoj ,imaginarnoj sposobnosti da odabere i posloži realnost“. Istovremeno, svoje slušatelje podsjeća na to da se sam Bog ne ophodi sa svima na temelju stroge pravde i ponekad se njegove lekcije čine nepoštenima, ali svakako su dio njegove volje koja je čudesna. Taj element iznenađenja na kraju mnogih njegovih prispodoba govori o neočekivanom krajnjem ponašanju lika iz priče, kojim poučava o onome kakav je Bog (Hultgren 2000, 10). Taj je kraj intrigantan i zbog toga što njegove prispodobe ne daju uvid u krajnji rasplet situacije, Isus ne daje cjelovit odgovor pa poučava tako što „vraća u naš um svjesnost o istinskoj dvosmislenosti u postupcima likova" (Breech 1989, 29), istovremeno ne intervenirajući odobravanjem ili ukorom tih postupaka (Breech 1989, 53).

Sporedni likovi, koje koristi, imaju objašnjenje za svoje postupke, dok postupci njegovih glavnih likova nisu potkrijepljeni motivom, oni su jednostavno „aktivni katalizatori događaja "koji svojim postupkom pokreću postupke drugih likova (Breech 1989, 71). Kao učitelj, ne koristi apstraktne pojmove, pridjevne opise ili teološke rasprave, već kroz jezik konkretnih metafora oslikava i približava Boga (Hultgren 2000, 10). Sadržajem budi nadu i optimizam (Jeremias 1972, 120). Prema Lambrechtu $(1974,129)$, Isus prispodobama ne nastoji biti u pravu, već želi zadobiti slušatelja, ne želi poraziti protivnike, već ih pridobiti, dok Jones (1999, 40) ističe kako je sam Isus bio jedinstvena Božja prispodoba koji je „utjelovio slobodu i ljubav i oproštenje i suosjećanje“, poistovjećujući se s otuđenima uzor je samodajuće ljubavi. Isus je prispodoba bez kraja te „[p]oput likova u svojim prispodobama, Isus živi u priči bez kraja“ (Breech 1989, 78).

Isus je koristio iskustvene parabole kako bi svoju vječnu pouku prenio u učenikove svakodnevice. U tom svom pedagoškom pristupu, Isus je bio konstruktivist, pristupao je učenju kao aktivnom procesu, ostvarenom u prirodnom okruženju, kroz iskustvo. Njegovu je pouku svaki slušatelj za sebe trebao shvatiti i persona- 
lizirati, a to je uključivalo prethodno stečeno znanje i iskustvo koje bi se zatim nadogradilo u procesu kritičkog razmišljanja. To su elementi konstruktivističkog pristupa učenju koje ćemo objasniti u sljedećem odlomku.

\section{Isusov model poučavanja i elementi konstruktivizma}

\subsection{Konstruktivistički pristup učenju}

Suprotno biheviorističkom, a kao nadogradnja kognitivističkom pristupu procesu učenja, nalazi se konstruktivistički pristup (Jukić 2013, 243). Jukić tako pojašnjava da se konstruktivistički pristup zasniva na aktivnom i konstantnom konstituiranju znanja, razvijanju i stvaranju vrijednosti i uvjerenja kroz nove probleme (situacije), odnosno slaganju osobnih spoznaja kojima se stvara realnost. Ovo je proces učenja u kojem se nadograđuje učenikovo prethodno znanje i umijeće, tako što se pri susretu s novom informacijom stvaraju nove spoznaje preko postojećih osobnih konceptualnih spoznaja (Robertson 2008, 2). U ovakvom učenju stvara se značenje, aktivno se gradi razumijevanje i znanje, dok se neprestano procjenjuje postojeće razumijevanje, odnosno kroz interakciju prijašnjeg iskustva $s$ novom informacijom. Obilježja konstruktivizma uključuju učenje kroz socijalnu interakciju, komunikaciju s okolinom, stjecanje iskustva i razumijevanja kroz jezik i kulturu u kojima novo znanje dobiva svoje značenje u doticaju s prethodnim iskustvom.

Robertson $(2008,2)$ ističe da se ovdje radi o pristupu s pet faza, poznatom kao i 5E modelu učenja, s fazama: uključivanje s pitanjem/frazom (Engagement), istraživanje (Exploration), oblikovanje objašnjenja (Explanation), prikaz i potvrđivanje spoznaje (Elaboration) te evaluacija ili vrednovanje (Evaluation). Kroz uključujući uvod, učenike se uključuje u ono što se treba usvojiti pa ih se na taj način stimulira entuzijazmom te ih se povezuje s određenim problemom (situacijom) i usmjerava da započnu s traženjem rješenja. Uključujuća fraza stvara znatiželju i aktivira kritičko promišljanje kroz stvarne i učeniku poznate teme. Faza istraživanja daje učeniku prostora za stvaranje iskustva iz kojeg može učiti, osobito kroz istraživanje društvenog problema u stvarno prikazanoj situaciji, tako što se izvlači zaključak iz problema i povezuje s opipljivom stvarnosti. Učenike u ovoj fazi potpuno apsorbira problem koji nastoje riješiti samostalno. Faza oblikovanja objašnjenja dopušta analizu i interpretaciju koncepta koji se istraživao, pomaže učeniku razviti vještine i stavove u učenju, a učitelju daje mogućnost za predstavljanje termina i definicija te usmjeravanje u učenju. Faza prikaza i potvrđivanja spoznaje stečene kroz iskustvo ima za namjeru proširiti postojeće znanje te staviti $\mathrm{u}$ funkciju to znanje u smislenom kontekstu. U zadnjoj fazi, fazi evaluacije, učenici i učitelj mogu vrednovati razumijevanje novog znanja i razvoja vještine. 


\subsection{Isus - konstruktivist}

Ako se još jednom osvrnemo na Isusovo korištenje prispodoba, onda možemo reći kako je Isus svojim uključujućim parabolama omogućio slušateljima da budu dio njegove pouke i povežu se s njegovom porukom. Parabole su često predstavljale problem koji su učenici trebali istražiti kako bi naučili istinu iz toga. Isus je na taj način poticao istraživanje društvenih pitanja i odnosa u kontekstu, jeziku i običajima, koji su učenicima bili poznati i bliski. Uporabom parabola, Isus je usmjeravao učenike u smjeru istraživanja i traženja odgovora na vlastita pitanja. Kroz priče, koje je koristio, Isus je učenike poučavao u kontekstu te im davao mogućnost da sami prikupe pojašnjenje, a potom bi im objašnjavao sadržaj svog učenja. Isus nije svoje učenike evaluirao kroz testove, ali ih je mogao procijeniti kroz njihovu mogućnost analiziranja, povezivanja i primjenjivanja naučenog u praksi.

Isusov model poučavanja primjer je netradicionalnog poučavanja, tj. onoga što danas nazivamo konstruktivističkim pristupom, i to zbog primjenjivanja starih i novih ideja, korištenjem relevantnih prikaza, propitkivanjem učenika, ostavljanjem nekih pitanja neodgovorenih, govoreći u ljubavi i s poštovanjem, promoviranjem kritičkog razmišljanja i poučavanjem kroz primjere (Roso 2010, 43).

\section{Konstruktivističke karakteristike u učenju na daljinu}

\subsection{Učenje na daljinu}

Iako korišteno, revolucionarizirano i aktualno u suvremenom obrazovanju, učenje na daljinu ima svoju povijest još od 19. stoljeća, kada se putem dopisivanja omogućavalo obrazovanje marginaliziranima (Katavić et al. 2018, 96). Lee (2017, 16) ističe da je možda nemoguće složiti se oko jasne definicije učenja na daljinu, no danas pod učenjem na daljinu uglavnom mislimo na užu kategoriju učenja na daljinu, odnosno na online (virtualno) učenje, korištenjem računala kao komunikacijskog medija kojim se prenose obrazovni sadržaji, uspostavlja komunikacija između učenika i predavača te održava cjelokupni nastavni proces. Najčešće spominjana odlika online učenja je fleksibilnost jer virtualno učenje u današnjim okolnostima je ne samo neophodno već i model koji pruža pristup obrazovanju u bilo koje vrijeme i na bilo kojem mjestu (Means et al. 2009, 1).

Još krajem devedesetih, Bonk i Dennen $(1999,5)$ upućivali su na moguće izazove koji nastaju s pritiskom promjene nastavnih i tehnoloških očekivanja učitelja i učenika prilikom pomaka s tradicionalnog na virtualno poučavanje. Primjerice, priprema učitelja traje puno duže i zahtijeva drugačiju pripremu, a od učenika se također zahtijevaju određene vještine i tehnološka pismenost. No oni također pojašnjavaju da virtualni svijet predstavlja intrigantno mjesto u kojem se može eksperimentirati i promisliti o vlastitu pristupu poučavanju. Možemo reći kako 
je online učenje mogućnost kojom se „razvijaju samoupravljajući učenici“, ali i dopušta kolaborativno dogovaranje oko značenja i zajedničko utvrđivanje razumijevanja (Garrison 2009, 95).

Virtualno obrazovanje nastalo je iz računalnih konferencija, a združilo se s konstruktivističkim pristupom učenja (Garrison 2009, 97), i to zbog svog nastojanja da se promjene pasivne pedagoške metode, zadrži pažnja i uključenost učenika kroz vrijeme i kroz kolaborativne nastavne sadržaje (Garrison 2009, 93). No online učenje u Hrvatskoj je i dalje samo alternativni pristup tradicionalnom poučavanju, čiji razvoj usporavaju kulturne i političke, a ne samo tehnološke postavke, ali istovremeno je to nužan pristup u okolnostima kada je ograničen pristup obrazovnim izvorima i kada se želi poboljšati kvaliteta obrazovanja (Katavić et al. 2018, 98). Ono što Katavić et al. tvrde, a ide u korak s konstruktivističkim pristupom u Isusovu načinu poučavanja, jest da online učenje učinkovitije vizualizira sadržaj. Isus je kustomerizirao svoj nastavni sadržaj prema potrebama svojih učenika te ih je poučavao kako učiti, baš kao što to suvremena online učionica zahtijeva od učitelja u pristupu učenju i poučavanju (Katavić et al. 2018, 101). Nadalje, kako se online učenjem nastoji učinkovitije pristupiti sadržaju, ono ima odliku provođenja ishoda učenja kroz kritički diskurs u zajedničkim nastojanjima nastavnog procesa, a za to je potreban pristup strukturiranog vođenja koji svrhovito upravlja prema značenju i razumijevanju (Garrison 2009, 98). A upravo to je Isus demonstrirao u svom pristupu sa svima koje je poučavao.

Međutim, s jedne strane postoje nedostaci online učenja, koji su tehničke i logističke naravi, ali i osobnog stava frustriranosti i manjka interesa (Katavić et al. 2018, 97), dok s druge strane postoje istraživanja koja pokazuju da virtualno učenje stvara jače ishode učenja kod učenika nego učenje isključivo u tradicionalnom frontalnom pristupu (Means et al. 2009, 18) te da se korištenjem obaju modela u poučavanju postižu jači ishodi učenja nego što to potiče isključivo tradicionalni pristup (Means et al. 2009, 19). Swan $(2005,8)$ navodi da postoje i istraživanja koja ukazuju na to da online učenje podupire konceptualno učenje više od tradicionalnog. Virtualno okruženje omogućava stvaranje aspekta socijalne prisutnosti i zajednice učenja u kojoj dolazi do zajedničkog stvaranja učinkovitoga kritičkog razmišljanja (Swan et al. 2009, 43).

\subsection{Konstruktivizam u online učenju}

Konstruktivistički pristup dolazi do izražaja i stavom da se apstraktne ideje računalom mogu predstaviti u konkretnom i razumljivom obliku te lakše povezati $s$ već postojećim znanjem, ispitati trenutne mentalne konstrukcije te dovesti do promjena u znanju, odnosno otkloniti zablude (Swan 2005, 3). Swan $(2005,5)$ naglašava da je online učenje korisno razmotriti upravo zato što se učenje ne od- 
vija isključivo unutar uma, već na društvenoj razini, uz pomoć alata i kulturnih artefakata.

Internet nudi prostor za mentorski odnos s učenicima te svi zadaci, savjeti i povratne informacije mogu biti vrlo individualizirani i pravovremeni. U skladu s konstruktivističkim pristupom, kada se pravilno predstave virtualni sadržaji diskusije, rasprave i argumentiranje članaka, oni mogu pomoći učenicima u smislenom usvajanju novih koncepata kroz povezivanje s prethodno stečenim iskustvima (Bonk i Dennen 1999, 12). Također, uloga učitelja u ovakvom okruženju dolazi do većeg izražaja u smislu vodiča ili usmjeritelja nego predavača, kada se u nastavnim aktivnostima može opredijeliti za one koji potiču učenikova područja interesa i snage. Na taj se način učenike može poticati na samostalno istraživanje i kritičko promišljanje o važnosti doprinošenja procesu učenja i popratnom djelovanju. Nasuprot tradicionalnom pristupu u učionici u kojoj se poučava pasivne učenike, $u$ virtualnoj učionici oni mogu postati aktivni sudionici koji zajedno $s$ ostalima izgrađuju značenje i stječu nova saznanja.

Konstruktivizam u online učenju daje nam prostor za razmišljanje o nastavnim teorijama i pedagoškim pristupima kojima se želimo odmaknuti od pukog prenošenja znanja do mjesta gdje učitelji i učenici zajedno stvaraju znanje (Fitzpatrick et al. 2009, 15). I u virtualnoj sredini možemo preslikavati Isusov karakter i njegov pristup, čije elemente nalazimo u suvremenom konstruktivističkom pristupu, te poticati učeničku kreativnost, aktivno sudjelovanje, kritičko razmišljanje i istraživanje te pronalaženje novih spoznaja koje potiču na stvarno djelovanje.

\section{Primjena}

Većina Isusova poučavanja iznesena je u neposrednoj blizini svojih učenika i slušatelja. Bio je učitelj koji je volio biti tik uz one koje poučava iako je u nekim trenucima morao poučavati udaljen od mnoštva, primjerice s lađice. Isus je bio drugačiji učitelj, razlikovao se od ostalih - koristio je inovativne metode, poučavao je i izvan mjesta predviđenog za pouku, imao je autoritet i karakter koji je privlačio brojna slušateljstva. Njegova metoda za poučavanje je bila priča s poukom, koja je zahtijevala određeni odgovor - stav ili popratno djelovanje. Poučavao je o stvarnim, dubokim i kontekstualnim lekcijama. Njegovo je učenje pozivalo na primjenu i promjenu. Njegova je metoda poučavanja imala za cilj slušatelje potaknuti na žestoko razmišljanje, ne poput neke pričice kojom suvremeni učitelji žele začiniti svoje pomalo suhoparno izlaganje, već da izazove na opredjeljenje i odlučno postupanje. U svom poučavanju, Isus prakticira radikalniju poruku koja privlači učenike, mijenja njihov stav i čini da ga uzmu za uzor i slijede. Jasno je da $\mathrm{u}$ svem svom poučavanju Isus vjeruje da njegovi slušatelji sa svim svojim manama i slabostima mogu biti putokazi prema Božjoj vladavini te u svojoj brizi i djelovanju shvatiti dublju brigu i djelovanje Boga (Hunter 1979, 14). 
Tematika Isusova poučavanja formulirana je oko ljudskog postojanja, muškaraca, žena i djece, sa svim njihovim usponima i padovima, a srž lekcije i odgovor koji se očekuje su teme koje se i danas tiču i naših učenika. Poput Isusa, možemo primjenjivati brigu u svom poučavanju, poput njega, ne praviti razliku među svojim učenicima te posegnuti prema onima koji imaju određene poteškoće. Kao učitelji, trebamo odvojiti vrijeme za svakoga pojedinog učenika ili studenta i nastojati razumjeti s kakvim se nedaćama nosi.

Isusove parabole su kratke i sažete, označene jednostavnošću i simetrijom, usredotočene na ljude, uključuju fiktivne opise primjenjive na svakodnevni život, uključujuće, često sadrže preokret, kontekstualne su, teocentrične i s ključnim završetkom (Snodgrass 2008, 17). Možemo navesti da su njegove pouke bile holističke jer su njegovi slušatelji usvajali znanje pomoću kojeg su mogli razumjeti svijet koji ih okružuje. U suvremenom kontekstu možemo svojim učenicima u procesu odgoja i obrazovanja dati pristup nastavnim sadržajima koji će odraziti takvo holističko shvaćanje svijeta.

U svom konstruktivističkome pristupu procesu učenja, Isus je poticao aktivno sudjelovanje učenika, nudio je pouku koja je bila povezana s učenikovim interesima i stilom učenja te svakako poboljšao njihovo učenje. Konstruktivistički pristup nije superiorniji tradicionalnom te ima svoja ograničenja u zanemarivanju kulture škole i širega društvenog okruženja u procesu učenja (Jukić 2013, 244). Smatra se teorijom učenja, a ne dijelom didaktike koja se provodi u nastavi. Pristup se oslanja na individualizaciju konstruktivnog učenja sa smanjenom ulogom poučavanja, no s mnogo mogućnosti povezivanja sadržaja drugih područja i svakodnevnog života. Upravo u današnjim okolnostima, kada se masovno i primorano poučava u sustavima učenja na daljinu, od svojih učenika i studenata očekujemo individualizaciju u učenju te konstruktivni karakter i autonomiju u učenju. Poput konstruktivističkih učitelja, možemo poticati i očekivati učenikovu samostalnost i inicijativu, motivirati učenike da koriste raznovrsne nastavne materijale dostupne u digitalnom svijetu, provjeriti učenikovo razumijevanje prije davanja vlastita tumačenja, ohrabrivati otvorena pitanja, razgovor i raspravu te stavljati učenike $\mathrm{u}$ iskustva proturječna prvotnim razumijevanjima, u motivirajućoj i zaigranoj atmosferi (Brooks i Brooks 1993, 109).

U nekim praktičnim smjernicama organiziranja online nastave, Gewin (2020, 295) predlaže da svaki nastavni sat bude vremenski ograničen na 40 minuta, dok se suština višesatne nastave predmeta može sažeti u videoprezentaciju ne dužu od 30 minuta, upozoravajući da učenici nisu voljni dugo gledati sadržaj bez glasa i lika učitelja. Zadaci koji se zadaju učenicima najučinkovitije se izvršavaju unutar 30 minuta, što je u skladu s Preporukama o organizaciji radnoga dana učenika tijekom održavanja nastave na daljinu (Ministarstvo znanosti i obrazovanja 2020, 7). Nadalje, Zheng i Zhu $(2020,12)$ zaključuju iz provedenog istraživanja da su 
najučinkovitiji načini za podučavanje praktičnih aspekata gledanje videozapisa određenih vještina te samostalno bilježenje i raščlanjivanje tih vještina.

\section{Zaključak}

U suvremenim okolnostima, u kojima su škole primorane odstupiti od svojih tradicionalnih didaktičkih pristupa, nastojimo kao učitelji izvući one karakteristike i praktične savjete iz načina na koji je Isus poučavao te ih primijeniti u današnjem procesu odgoja i obrazovanja. Isus je bio drugačiji učitelj, inovativni metodičar, ispred svog vremena, a svojim metodama je znao zaintrigirati slušatelje i potaći ih na aktivno učenje i djelovanje. U svom pristupu koristio je, suvremenom terminologijom - konstruktivističke paradigme, $\mathrm{u}$ kojima mu njegovi slušatelji predstavljaju subjekt nastavnog procesa. Znao je da učenje ovisi o njihovu predznanju te da će novu koncepciju koju im predstavlja moći usvojiti kroz mijenjanje starih, čime želi da oni ne kumuliranju nove informacije, već da smisleno mijenjaju stare stavove i stvaraju nove zaključke. Njihovo je učenje bilo pod utjecajem konteksta u kojem su bili poučavani te se od njih zahtijevalo da budu uključeni, da istražuju i promišljaju o onome što se uči, kroz provokativne izazove svakodnevnih problema, čije rješenje nudi tumačenje novih znanja, a njih se na kraju formativno evaluira.

Ovaj kratki članak pruža jedino predukus pojmova, pristupa i sadržajnih komponenti koje različiti autori pomno istražuju i produbljuju te otkrivaju neslaganja s drugim autorima. Isusove parabole su tema mnogih pisaca, s raznolikim tumačenjem i ponudama za primjenom. Također, konstruktivistički pristup procesu učenja nailazi na duboka razlaganja i sadrži različite pravce te oprečne stavove konzervativnijih kršćanskih učitelja (Roso 2010,3). Učenje na daljinu je jedan od pojmova u moru virtualnih naziva za ovakvo poučavanje te iza sebe ima cijelu teoriju i objašnjenje modela unutar pristupa. Sve su to smjernice za moguće daljnje istraživanje i sužavanje područja istraživačkog interesa.

Nama učiteljima preostaje da u svojim nastojanjima prenošenja znanja, umijeća, vještina i vrijednosti, razmislimo o pristupu koji je Isus primjenjivao i budemo što sličniji njemu. Poput primjera koji nam Isus daje, u svojem didaktičkom pristupu možemo nastojati prepoznati učenikova iskustva, kao vrijednu individualnu stvarnost, te ih koristiti u povezivanju nastavnih sadržaja. Pristupati učeniku s karakterom koji je Isus pokazivao - s ljubavlju i s poštovanjem, poticati ih i usmjeravati, animirati i mijenjati stare koncepcije, s onim novim, vrijednim i vječnim. 


\section{Literatura}

Bailey, Kenneth E. 1983. Poet and Peasant and Through Peasant Eyes: A LiteraryCultural Approach to the Parables of Luke. Grand Rapids: Eerdmans.

Bonk, Curtis Jay i Vanessa Dennen. 1999. „Teaching on the Web: With a Little Help from My Pedagogical Friends". Journal of Computing in Higher Education, 11 (1): 3-28.

Breech, James. 1989. Jesus and Postmodernism. Minneapolis: Fortress Press.

Brooks, J. G., i M. G. Brooks. 1993. In Search of Understanding: The Case for Constructivist Classrooms. Alexandria: Association for Supervision and Curriculum Development.

Fitzpatrick, N., Nóirín Hayes, i K. C. O’Rourke. 2009. „Beyond Constriction and Control: Constructivism in Online Theory and Practice“. U: C. R. Payne, ur. Information Technology and Constructivism in Higher Education: Progressive Learning Frameworks, 14-26. Hershey: IGI Global.

Garrison, R. 2009. „Implications of online learning for the conceptual development and practice of distance education". Journal of Distance Education 23 (2): 93-104.

Gewin, V. 2020. „Five tips for moving teaching online as COVID-19 takes hold“. Nature 580: 295-296.

Hultgren, Arland J. 2000. The Parables of Jesus: A Commentary. Grand Rapids: William B. Eerdmans Publishing Company.

Hunter, A. M. 1979. The Parables Then and Now. London: SCM Press Ltd.

Jeremias, Joachim. 1972. The Parables of Jesus. New York: Charles Scribner's Sons.

Jones, Peter Rhea. 1999. Studying the Parables of Jesus. Macon: Smyth \& Helwys Publishing, Inc.

Jukić, R. 2013. „Konstruktivizam kao poveznica poučavanja sadržaja prirodoznanstvenih i društvenih predmeta“. Pedagogijska istraživanja 10 (2): 241-63.

Katavić, Ivica, Dimitrije Milojević i Mario Šimunković. 2018. „Izazovi i perspektive online obrazovanja u Republici Hrvatskoj". Obrazovanje za poduzetništvo 8 (1): 95-107.

Lambrecht, Jan. 1974. „The Message of the Good Samaritan“. Louvain Studies 5: 121-35.

Lee, Kyungmee. 2017. „Rethinking the accessibility of online higher education: A historical review“. Internet and Higher Education 33: 15-23. 
Means, Barbara, Yukie Toyama, Robert Murphy, Marianne Bakia i Karla Jones. 2009. Evaluation of Evidence-Based Practices in Online Learning: A MetaAnalysis and Review of Online-Learning Studies. Washington, D.C.: US Department of Education.

Ministarstvo znanosti i obrazovanja u RH. 2020. Preporuke o organizaciji radnoga dana učenika tijekom održavanja nastave na daljinu. Zagreb.

Porton, Gary G. 2006. „The Parable in the Hebrew Bible and Rabbinic Literature“. U: Levine, Amy-Jill, Dale C. Allison Jr, i John Dominic Crossan, ur. The Historical Jesus - in Context, 206-221. Princeton: Princeton Readings in Religions.

Robertson, William H. 2008. „The Greatest Constructivist Educator Ever: The Pedagogy of Jesus Christ in the Gospel of Matthew in the Context of the 5Es“. Christian Perspectives in Education 1 (2): 1-17.

Roso, Calvin G. 2010. „Constructivism in the Classroom: Is It Biblical?“ U: HeeKap Lee, ur. Faith-Based Education That Constructs, 38-45. Eugene: Wipf and Stock Publishers.

Schottroff, Luise. 2006. The Parables of Jesus. Minneapolis: Fortress Press.

Snodgrass, Klyne. 2008. Stories with Intent: A Comprehensive Guide to the Parables of Jesus. Grand Rapids: William B. Eerdmans Publishing Company.

Stein, Robert H. 1978. The Method and Message of Jesus' Teachings. Philadelphia: The Westminster Press.

Swan, K. 2005. „A constructivist model for thinking about learning online“. U: J. Bourne i J. C. Moore, ur. Elements of Quality Online Education: Engaging Communities, 1-19. Needham, MA: Sloan-C.

Swan, K., Garrison, D. R. i Richardson, J. C. 2009. „A constructivist approach to online learning: the Community of Inquiry framework“. U: C. R. Payne, ur. Information Technology and Constructivism in Higher Education: Progressive Learning Frameworks, 43-57. Hershey: IGI Global.

Zheng, T. i Xinhong Zhu. 2020. „Comparing the effects of online teaching during the COVID-19 pandemic and traditional teaching in Surgical Nursing" [preprint]. https://www.researchgate.net/publication/347005974_ Comparing_the_effects_of_online_teaching_during_the_COVID-19_ pandemic_and_traditional_teaching_in_Surgical_Nursing (pristupljeno 25. veljače 2021.). 
Maja Seguin

What Would Jesus do in a Distance Learning Mode of Teaching?

\begin{abstract}
Several pedagogical considerations come with the transition from traditional to virtual teaching, and it is necessary to provide teachers with a potential approach to teaching and learning. This article gives an overview of the teaching methods Jesus used with a focus on parables, highlights the modern constructivist approach to teaching, and singles out characteristics of constructivism in Jesus' teaching model. Combined, this presents a basis for practical advice in today's context of online teaching, respectively in a virtual setting. The article highlights characteristics of Jesus as a teacher which present-day teachers can apply to their contexts and finishes with suggestions for further research.
\end{abstract}

